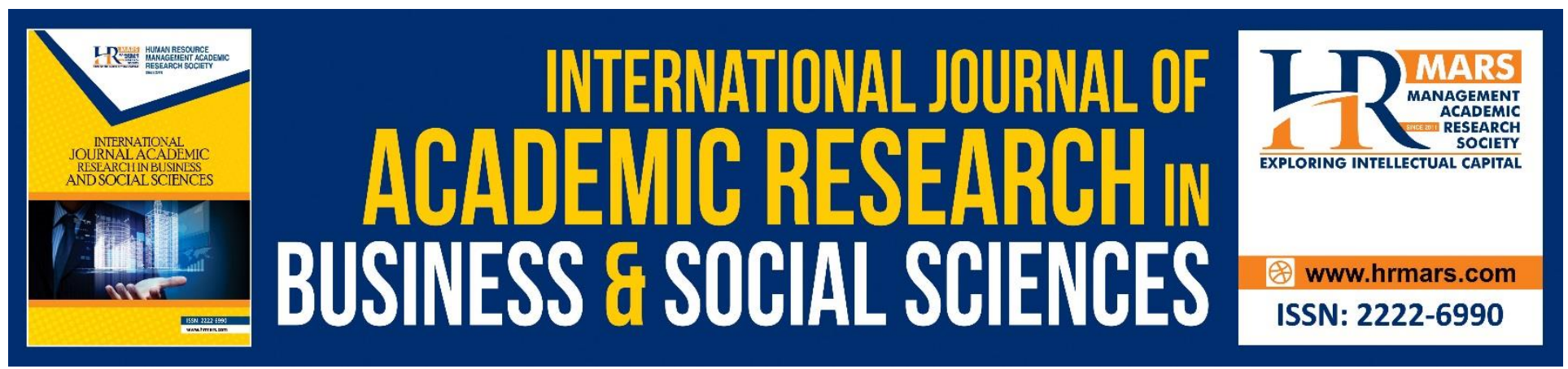

\title{
An Error Analysis Approach in Identifying the Patterns of Mistakes in Jawi Spelling
}

Asyraf Ridwan Ali, Berhanundin Abdullah, Norfadzilah Rashid

To Link this Article: http://dx.doi.org/10.6007/IJARBSS/v8-i11/5164

DOI: $10.6007 /$ IJARBSS/v8-i11/5164

Received: 19 Oct 2018, Revised: 26 Nov 2018, Accepted: 30 Nov 2018

Published Online: 02 Dec 2018

In-Text Citation: (Ali, Abdullah, \& Rashid, 2018)

To Cite this Article: Ali, A. R., Abdullah, B., \& Rashid, N. (2018). An Error Analysis Approach in Identifying the Patterns of Mistakes in Jawi Spelling. International Journal of Academic Research in Business and Social Sciences, 8(11), 1222-1231.

Copyright: (C) 2018 The Author(s)

Published by Human Resource Management Academic Research Society (www.hrmars.com)

This article is published under the Creative Commons Attribution (CC BY 4.0) license. Anyone may reproduce, distribute, translate and create derivative works of this article (for both commercial and non-commercial purposes), subject to full attribution to the original publication and authors. The full terms of this license may be seen

at: $\underline{\text { http://creativecommons.org/licences/by/4.0/legalcode }}$

Vol. 8, No. 11, 2018, Pg. 1222 - 1231

Full Terms \& Conditions of access and use can be found at http://hrmars.com/index.php/pages/detail/publication-ethics 


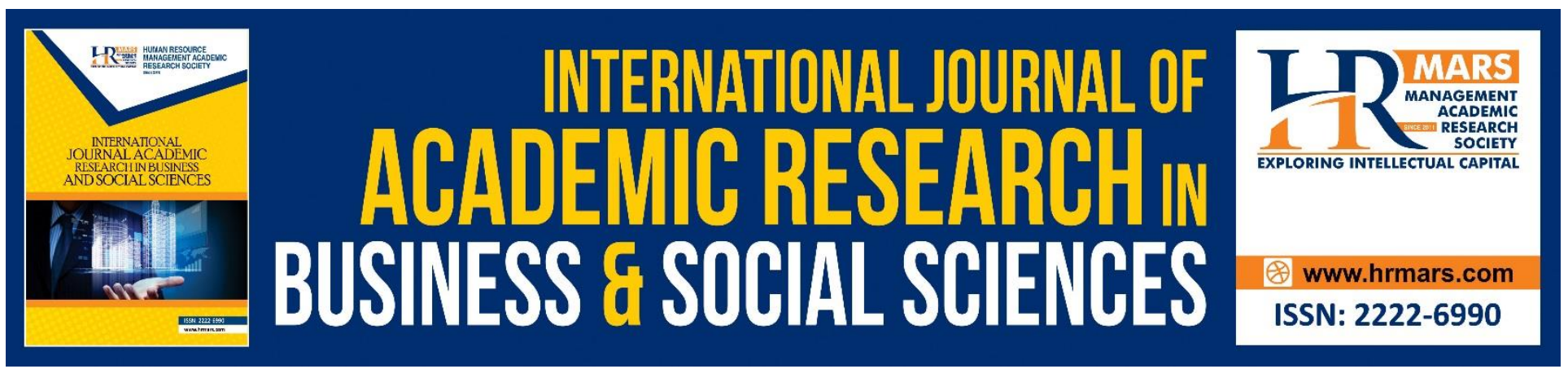

\title{
An Error Analysis Approach in Identifying the Patterns of Mistakes in Jawi Spelling
}

\author{
Asyraf Ridwan Ali, Berhanundin Abdullah, Norfadzilah Rashid \\ ${ }^{1}$ Institut Pendidikan Guru Kampus Dato' Razali Ismail, Terengganu, Malaysia. \\ ${ }^{2}$ Fakulti of Islamic Contemporary, University of Sultan Zainal Abidin, Malaysia. \\ ${ }^{3}$ Faculty of Economics and Management Sciences, Universiti Sultan Zainal Abidin, 21300 Kuala \\ Nerus, Terengganu, Malaysi \\ Corresponding Author: berhan@unisza.edu.my.
}

\begin{abstract}
The implications of the neglecting jawi writing for two decades (1963-1983) have given a great impact on the mastery of jawi texts among Malay citizens in Malaysia. Although various efforts have been made to uplift jawi writing, the efforts are yet not really successful. The issues and problems in mastering this writing skill are still a problem to the public, including teachers and students. The methodology of this study uses the error analysis approach by Corder (1974) to assess the strengths and weaknesses faced by the teachers of Islamic Education (normally known as GPI teachers). The results of the $415 \mathrm{GPI}$ teachers on the nine roman words that need to be spelled out showed that some GPI teachers do not master the jawi writing skills well. There are twelve patterns of spelling mistakes for the word "subjek" (subject), followed by eleven patterns of spelling mistakes for the word "anbia" (prophets), nine patterns of spelling mistakes for the word "air" (water), eight patterns of spelling mistakes for the word "emak" (mother), seven patterns of spelling mistakes for the words "wap" (steam), six patterns of spelling mistakes for the word "kiambang" (duckweed), four patterns of spelling mistakes for the word "seminar" (seminar), three patterns of spelling mistakes for the word "sabun" (soap) and one pattern of spelling mistake for the word "bab" (chapter). The findings clearly show that GPI teachers are still inexperienced to transcribe roman-jawi words accurately. Hence, in this study the error analysis approach was implemented to identify and assist teachers to master the jawi based on jawi writing skills more accurately and effectively.
\end{abstract}

Keywords: Error Analysis, Patterns, Jawi, Spelling Mistakes.

\section{Introduction}

The challenges in $21^{\text {st }}$ century education system require teachers to be prepared, creative and critical in delivering their teaching including in Jawi teaching. Each teacher should not only have to equip themselves with effective Information Technology and Communication (ICT) skills, good in teaching 
INTERNATIONAL JOURNAL OF ACADEMIC RESEARCH IN BUSINESS AND SOCIAL SCIENCES Vol. 8, No. 11, Nov, 2018, E-ISSN: 2222-6990 (C) 2018 HRMARS

and facilitating $(\mathrm{PnF})$ skills. It also requires high pedagogical and metacognitive skills to face the increasingly brave and challenging students' attitudes.

This Error Analysis (EA) approach is selected in line with the uniqueness of the Malay language which has two forms of writing ie roman script and jawi script. As an impact of being neglected for two decades (1963 to 1983), the issues and the mastery of jawi script has given a negative impact among its users including the teachers themselves. The influence of roman writing and the absorption of foreign language into Malay language has indirectly affected the spelling system of jawi.

Therefore, the teachers need to improve their Jawi writing skills as well as analyze the root causes of their weaknesses. In addition, this approach indirectly helps them to improve the weakness of Jawi mastery among students. The EA approach can be used as an alternative suggestion to reduce the mistakes of jawi spelling in teaching and learning among teachers.

Generally, the flow of Error Analysis arose from dissatisfaction with the view of Contrastive Analysis flows by Mathesius (1926), Fries (1945), Wardhaugh (1970), Lado (1977) and Fisiak (1981). The flow of EA appeared in the 1960s by Corder (1967), Richards (1971), Selinker (1972), Politzer and R Ramirez (1973), also Richards and Sampson (1974). This flow also studies the language transfer errors that arise as a result of the teaching and learning strategy mistakes (Richards, 1992).

The conclusion is, EA is a step taken for the research and to collect the information, classify errors and define language errors. In this study, Jawi test was carried out to identify the pattern and the degree of how serious errors were made in Jawi writing based on error analysis approach.

\section{The Problem Statement}

The previous studies have shown that Islamic Education teachers face problems in writing Jawi. The research of Mohd Mazhan and Syarifah Nor (2013) found that teachers failed to understand Jawi curriculum which applied in the teaching and learning process in the classroom. There is even a claim that Islamic Education teachers are also 'blind' in Jawi (Hasmadi, 2012). The research of Asyraf Ridwan (2011) also showed that some of the jQAF teachers (now known as GPI teachers) still make mistakes in jawi writing. The research of Abd Rahman Hamzah (2008) found that teachers also made mistakes and were unskilled when writing jawi.

In this research, a preliminary survey was conducted to study language error patterns according to error analysis approach. The selection of this approach is considered to be appropriate to this research as it included the process of error analysis in the flow of approaches such as the abortion issue of the necessary elements, incorrect addition of elements, inaccurate selection of elements and misstatement of elements.

However, in order to identify mistakes in the spelling of jawi words, the limitations of the study only focus on the test based on the structure of the word alone. The study focuses only on mechanical 
INTERNATIONAL JOURNAL OF ACADEMIC RESEARCH IN BUSINESS AND SOCIAL SCIENCES Vol. 8, No. 11, Nov, 2018, E-ISSN: 2222-6990 C 2018 HRMARS

and spelling errors on nine selected words to test Jawi spelling skills. The study aims is to explore and identify fault patterns made by GPI teachers when translating roman words into Jawi words.

\section{Methodology}

In this study, a preliminary survey was conducted to examine the language error patterns according to an error analysis approach. The Jawi test was given to 415 respondents among GPI teachers in Terengganu state. The answer was analyzed using an error analysis approach by Corder's (1974). He has outlined four common mistakes, that are: (a) abortion of the necessary elements, (b) the addition of unnecessary or incorrect elements, (c) improper selection of elements; and (d) the preparation of the wrong element.

Although this research only selected nine words to spell, but the researcher has succeeded in displaying the real scenario faced by some GPI teachers when writing jawi words. This difficulty is seen as a result of the difficulty in mastering the diversity of methods in the irregular jawi system, which often changing or in understanding the existing exemptions.

\section{The Results}

Error Analysis is a language research process that includes data collection steps, identifying mistakes, defining errors, confirming errors and defining faults (Ellis, 1988). The results of the jawi writing test on 415 Teachers of Islamic Education indicate that there are various patterns of jawi spelling mistakes for the nine words given. The aim of this study is to find out the errors that some GPI teachers make in writing Jawi words.

\section{Research Question 1:}

\section{What of the forms of jawi writing mistakes by GPI teachers?}

The findings showed that more than half respondents failed to answer exactly three of the nine tested words. For the word "air" (water), 150 GPIs (36.14\%) answered correctly, the word "anbia" (prophets), $128 \mathrm{GPIs}$ (36.14\%) answered correctly and the word 'seminar' (seminar), 63 GPIs (15.18\%) answered correctly.

While the remaining six words, the study found that 267 GPIs (64.34\%) were able to spell the word "wap" (steam) accurately and 148 GPIs (35.66\%) misspelled that word. For the word "sabun (soap), 360 GPIs (86.75\%) spelled correctly and the rest 55 GPIs (13.25\%) did not successfully spell the word. For the word "subject" (subject), 227 GPIs (54.70\%) spelled correctly and 188 GPIs (45.30\%) misspelled the word. For the word "kiambang" (duckweed), a total of 367 GPIs (88.43\%) spelled correctly and the rest 48 GPIs (11.57\%) misspelled that word. For the word "bab" (chapter), $383 \mathrm{GPIs}$ (92.29\%) spelled correctly and the rest $32 \mathrm{GPIs}(7.71 \%)$ misspelled the word. The results are as the following table below: 
INTERNATIONAL JOURNAL OF ACADEMIC RESEARCH IN BUSINESS AND SOCIAL SCIENCES

Vol. 8, No. 11, Nov, 2018, E-ISSN: 2222-6990 @ 2018 HRMARS

Table 1: Jawi Test Results

\begin{tabular}{cccccc}
\cline { 2 - 6 } & \multicolumn{2}{c}{ Words } & \multicolumn{2}{c}{ correct } & \multicolumn{2}{c}{ incorrect } \\
& (malay) & F & $\%$ & F & $\%$ \\
\cline { 2 - 6 } 1. & Wap & 267 & $64.34 \%$ & 148 & $35.66 \%$ \\
2. & Bab & 383 & $92.29 \%$ & 32 & $7.71 \%$ \\
3. & Air & 150 & $36.14 \%$ & 265 & $63.86 \%$ \\
4. & Sabun & 360 & $86.75 \%$ & 55 & $13.25 \%$ \\
5. & Emak & 379 & $91.33 \%$ & 36 & $8.67 \%$ \\
6. & Subjek & 227 & $54.70 \%$ & 188 & $45.30 \%$ \\
7. & Kiambang & 367 & $88.43 \%$ & 48 & $11.57 \%$ \\
8. & Anbia & 128 & $30.84 \%$ & 287 & $69.16 \%$ \\
9. & Seminar & 63 & $15.18 \%$ & 352 & $84.82 \%$ \\
\hline
\end{tabular}

$$
\mathrm{N}=145 \mathrm{GPIS}
$$

Based on the results of the test, the level of Jawi spelling among GPI teachers are still at an alarming level. This is because some GPI teachers do not just fail to answer the test correctly, but they even weak in spelling jawi words, especially for foreign language loanwords and to understand the function of 'hamzah'.

\section{Research Question 2 :}

What are the patterns of errors that GPI teachers make in the writing Jawi word?

The findings of both studies showed that some GPI teachers do not understand the law of correctness and the latest jawi spelling system correctly. The findings of the study clearly showed that some GPIs are still confused and hesitant to spell jawi words. The following Table 2 to 4 show the findings: 
INTERNATIONAL JOURNAL OF ACADEMIC RESEARCH IN BUSINESS AND SOCIAL SCIENCES Vol. 8, No. 11, Nov, 2018, E-ISSN: 2222-6990 @ 2018 HRMARS

Table 2: Spelling Mistakes Patterns (One Syllabe)

\begin{tabular}{|c|c|c|c|c|c|c|}
\hline $\begin{array}{c}\text { Malay } \\
\text { (English) }\end{array}$ & $\begin{array}{c}\text { AlR } \\
\text { (water) }\end{array}$ & Total & $\begin{array}{c}\text { WAP } \\
\text { (steam) }\end{array}$ & Total & $\begin{array}{c}\text { BAB } \\
\text { (chapter) }\end{array}$ & Total \\
\hline Correct & | أير & 150 & وروف & 267 & باب & 383 \\
\hline \multirow[t]{9}{*}{ Incorrect } & اير & 87 & و & 126 & ب & 32 \\
\hline & |بير & 123 & iy & 1 & & \\
\hline & | اير & 12 & واف & 2 & & \\
\hline & | اير | & 10 & ور & 13 & & \\
\hline & أير & 22 & وف & 3 & & \\
\hline & إير & 3 & ورب & 2 & & \\
\hline & ائر & 4 & وب & 1 & & \\
\hline & كاير & 3 & & & & \\
\hline & وا & 1 & & & & \\
\hline
\end{tabular}

Table 3: Spelling Mistakes Patterns (Two Syllabes)

Two Syllables

\begin{tabular}{|c|c|c|c|c|c|c|}
\hline $\begin{array}{c}\text { Malay } \\
\text { (English) }\end{array}$ & $\begin{array}{l}\text { SUBJEK } \\
\text { (subject) }\end{array}$ & Total & $\begin{array}{c}\text { EMAK } \\
\text { (mother) }\end{array}$ & Total & $\begin{array}{l}\text { SABUN } \\
\text { (soap) }\end{array}$ & Total \\
\hline Correct & سوبيكى & 227 & امثَ & 379 & سابون & 360 \\
\hline \multirow[t]{12}{*}{ Incorrect } & 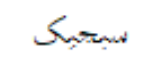 & 18 & أمثي & 26 & صايون & 51 \\
\hline & سبجبك & 18 & المن & 1 & صبون & 3 \\
\hline & سوبيكبك & 49 & إهمث & 1 & سبون & 1 \\
\hline & سيب:جباك & 1 & إلهنت & 26 & & \\
\hline & سوجبك & 1 & إمتى & 3 & & \\
\hline & سابريك & 1 & إيمك & 1 & & \\
\hline & سبجيث & 25 & امكك & 1 & & \\
\hline & سوبيتين & 71 & امثت & 1 & & \\
\hline & سوبجتَ & 1 & & & & \\
\hline & سابيتين & 1 & & & & \\
\hline & سجين & 1 & & & & \\
\hline & سوفتيمين & 1 & & & & \\
\hline
\end{tabular}

$\mathrm{N}=415$ 
INTERNATIONAL JOURNAL OF ACADEMIC RESEARCH IN BUSINESS AND SOCIAL SCIENCES

Vol. 8, No. 11, Nov, 2018, E-ISSN: 2222-6990 @ 2018 HRMARS

Table 4: Spelling Mistakes Patterns (Three Syllabes)

\begin{tabular}{|c|c|c|c|c|c|c|}
\hline \multicolumn{7}{|c|}{ Three Syllables } \\
\hline $\begin{array}{c}\text { Malay } \\
\text { (English) }\end{array}$ & $\begin{array}{c}\text { ANBIA } \\
\text { (prophets) }\end{array}$ & Total & $\begin{array}{l}\text { KIAMBANG } \\
\text { (duckweed) }\end{array}$ & Total & $\begin{array}{l}\text { SEMINAR } \\
\text { (seminar) }\end{array}$ & Total \\
\hline Correct & انيباء & 128 & كمبامئ & 367 & سمبنر & 43 \\
\hline \multirow{11}{*}{ Incorrect } & انبيها؛ & 71 & كبمسيع & 32 & ( & 334 \\
\hline & 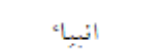 & 74 & S Sonn & 4 & ميمنار & 35 \\
\hline & أنبياء & 23 & كبnمن & 2 & سبمهينار & 1 \\
\hline & انبيا & 59 & كبامبام & 3 & منمنار & 3 \\
\hline & أنبياء & 25 & كامعغ & 1 & & \\
\hline & أنبيا & 3 & كياءمبع & 1 & & \\
\hline & |cنيبا & 1 & كبئمسا & 1 & & \\
\hline & امبياء & 16 & قو & 2 & & \\
\hline & امبيا & 12 & gِ & 1 & & \\
\hline & أمبِبا، & 1 & g thengh & 1 & & \\
\hline & أبيا & 2 & & & & \\
\hline
\end{tabular}

The results of the jawi test clearly showed that some teachers are still confused and hesitant when changing the roman words into jawi scripts. The findings also illustrated that most of the GPI teachers are weak in spelling the absorption words of English and Arabic.

\section{Discussion}

According to Corder (1985) these spelling mistakes can occur in the form of lapses, mistakes and errors. Accidental offenses of 'lapses' are caused by unintentional speech or misrepresentation. While the 'mistakes' occur due to the inability of speakers or writers to use appropriate and accurate words. And the 'errors' can occur as a result of its users have not mastered the language method until it became certain patterns.

The patterns of this language mistake are unpleasant mistakes especially by the teachers who teach and curriculum builders (George, 1972). These patterns of error usually occur due to; (i) the existence of the difference between the original language with the target language which being studied, the wrong assumption and the extreme generalization (Brown, 2000), (ii) lack of focus, fatigue or negligence among students in learning the language (Richards et al., 1992), (iii) doing mistakes during the language transfer process due to the interruption of the mother tongue (Corder, 1971), and (iv) the negative influence of the mother tongue in the acquisition of the target language (Lado, 1964). 
The results of the study found that GPI teachers had made some mistakes that formed certain patterns of errors in the spelling of jawi. These errors and mistakes can affect the mastery of spelling skills and smooth teaching among the teacher. These are the problems occurred from the errors:

i. Unable to identify the correct 'hamzah' position,

ii. Failed to understand the law in abolishing or retaining the alphabet 'alif' for closed syllables,

iii. Unable to identify the exact letters of English and Arabic language in absorption words,

iv. Switched the transliteration of the alphabet 'Pa' to 'Fa' or 'Ba', and

v. Confused in using the alphabet 'Kaf' for jawi and Arabic script.

The mistake in jawi spelling is due to the failure of the teacher to change the roman script to the jawi script correctly. This mistake can occur as a result of inability to use the appropriate word and error (mistake) or the jawi author does not master the language method until it creates certain error patterns. This situation indirectly affects the jawi learning process of their students. The following table shows the number of error patterns that GPI teachers have done.

Table 5 :Spelling Mistakes Patterns

\begin{tabular}{|c|c|c|c|c|c|c|c|c|c|}
\hline $\begin{array}{c}\text { Word } \\
\text { (Malay } \\
\text { ) }\end{array}$ & Wap & Bab & Air & Sabun & Emak & $\begin{array}{c}\text { Subje } \\
k\end{array}$ & $\begin{array}{c}\text { Kiamban } \\
\mathrm{g}\end{array}$ & Anbia & $\begin{array}{c}\text { Semina } \\
r\end{array}$ \\
\hline $\begin{array}{l}\text { Num. } \\
\text { of } \\
\text { error }\end{array}$ & $\begin{array}{c}7 \\
\text { patter } \\
n\end{array}$ & $\begin{array}{c}1 \\
\text { patter } \\
\mathrm{n}\end{array}$ & $\begin{array}{c}9 \\
\text { patter } \\
\mathrm{n}\end{array}$ & $\begin{array}{c}3 \\
\text { patter } \\
\mathrm{n}\end{array}$ & $\begin{array}{c}8 \\
\text { patter } \\
n\end{array}$ & $\begin{array}{c}12 \\
\text { patter } \\
n\end{array}$ & $\begin{array}{c}6 \\
\text { pattern }\end{array}$ & $\begin{array}{c}11 \\
\text { patter } \\
n\end{array}$ & $\begin{array}{c}4 \\
\text { pattern }\end{array}$ \\
\hline
\end{tabular}

$\mathrm{N}=145 \mathrm{GPI}$

Table 5 clearly showed that the pattern of the most incorrect word is the word 'subjek' (subject), followed by the word 'anbia' (prophets) and the word 'air' (water). The confusion in spelling the word illustrated that some teachers still lack understanding of the latest jawi spelling system and methodology as well as not yet proficient in writing jawi words. This is exactly like the theory proposed by Corder (1985).

\section{Conclusion}

The efforts to empower jawi texts need to be further improved either among students and teachers themselves. This is because, the GPI teacher who is the rigid practitioner of this writing has not been able to master the textual jawi skills completely, not to mention the other groups especially the public and the students.

Lack of exposure about the latest methods in Jawi systems through workshops and courses, the problems in the jawi spelling system itself and the effects of this article's neglection are seen as the main factor that makes this jawi writing difficult to master. Hence, this error analysis approach is seen 
INTERNATIONAL JOURNAL OF ACADEMIC RESEARCH IN BUSINESS AND SOCIAL SCIENCES

Vol. 8, No. 11, Nov, 2018, E-ISSN: 2222-6990 (C) 2018 HRMARS

as an excellent step in identifying and correcting the weaknesses of teachers and students in mastering jawi texts.

\section{References}

Brown, H.D. (1987). Principles of language learning and teaching. $2^{\text {nd }}$ ed. Englewood Cliffs. N.J.: Prentice-Hall, Inc.

Brown, G. \& George, Y. (1993). Discourse Analysis. Cambridge University Press.

Brown, D.B. (1994). Principles of Language Learning and Teaching. Third Edition. New Jersey: Prentice Hall Regents.

Corder, S.P. (1985). Error Analysis and Interlanguage. Oxford: Oxford University Press.

Corder, S.P. (1967). The significance of learners' errors. Reprinted in J.C.Richards (ed.) $(1974,1984)$ Error Analysis: Perspectives on Second Language Acquisition. London: Longman, pp. 19 - 27 (Originally in International Review of Applied Linguistics, 5 (4)).

Corder, S.P. (1971). Idiosyncratic errors and Error Analysis. IRAL, 9, 2, 147-159. Reprinted in Richards (1974)

Corder, S. P. (1974). Error Analysis. In J. P. B. Allen and S. Pit Corder (eds.) Techniques in Applied Linguistics (The Edinburgh Course in Applied Linguistics:3), London: Oxford University Press (Language and Language Learning), pp. 122-154.

Dewan Bahasa dan Pustaka. (2008). Daftar Kata Bahasa Melayu Rumi-Sebutan-Jawi, Cetakan 3. Kuala Lumpur: Dewan Bahasa Dan Pustaka.

Dewan Bahasa dan Pustaka. (1986). Pedoman Ejaan Jawi Yang Disempurnakan. Kuala Lumpur: Dewan Bahasa dan Pustaka, Kementerian Pendidikan Malaysia.

Ellis. R. (1994). The Study of Second Language Acquisition. Oxford:Oxford University Press.

Ellis, R. (1995). Understanding Second Language Acquisition. Oxford: Oxford University Press.

Ellis, R. (1997). SLA Research and Language Teaching. Oxford: Oxford University Press.

Fries, C.C. (1945). Teaching and Learning English as a Foreign Language. Ann Arbor. University of Michigan Press.

Gass, S. and Selinker, L. (2001). Second language acquisition: an introductory course. Mahwah, NJ: LEA, chapter 3.2. 
INTERNATIONAL JOURNAL OF ACADEMIC RESEARCH IN BUSINESS AND SOCIAL SCIENCES

Vol. 8, No. 11, Nov, 2018, E-ISSN: 2222-6990 C 2018 HRMARS

George, H.V. (1972). Common errors in language learning. Rowley, Massachusetts.

Hasmadi bin Hassan. (2012). Tulisan Jawi: Perkembangan dan peranannya menuju kemandulan dan kepupusan. Kertas kerja dalam Seminar Tulisan Jawi dan Teknologi 2012. Kuantan, Universiti Malaysia Pahang.

Lado, R. (1957). Linguistics across cultures. Ann Arbor, University of Michigan Press.

Lado, R. (1964). Language Teaching: A Scientific Approach. McGraw-Hill

Mohd Mazhan Tamyis, Sharifah Nor Puteh. (2013). Tahap keprihatinan guru j-QAF dalam melaksanakan inovasi program pemulihan Jawi. Seminar Kebangsaan Penyelidikan j-QAF 2013 (SKP j-QAF2013) Bangi: Puri Pujangga, Universiti Kebangsaan Malaysia.

Oldin, T. (1989). Language Transfer. Cambridge University Press

Oldin, T. (1992). Transferability and linguistic substrates. Second Language Research, 8, 3: 171-202.

Richards, J.C. (ed.) (1974). Error Analysis. Perspectives on second language acquisition. London: Longman.

Richards, J. (1974). A Non-Contrastive Approach to Error Analysis. In Richards, J. (Ed.). Error analysis: Perspectives on Second Language Acquisition. 172-188. Essex: Longman.

Richards, J.C. and G.P. Sampson (1974). The study of learner English. In J.C. Richards (ed.) Error Analysis. Perspectives on second language acquisition, pp. 3-18.

Richards, J.C. (ed.). (1992). Error Analysis: Perspectives on Second Language Acquisition. Longman Group Limited.

Selinker, L. (1974). Interlanguage. In Richards, J. (Ed.). Error analysis: Perspectives on Second Language Acquisition. 31-54. Essex: Longman.

Selinker, L. (1992). Rediscovering Interlanguage. New York. Longman.

Za'ba. (2009). Rahsia ejaan Jawi. Asmah Hj Omar (trans.). Kuala Lumpur: Dewan Bahasa dan Pustaka. 